\title{
Determination of Fenobucarb and Chlorbenside in Wastewater and Lake Water Samples by Gas Chromatography Mass Spectrometry
}

\author{
Dotse Selali Chormey ${ }^{1,2 *}$ \\ ${ }^{1 *}$ Yildiz Technical University, Faculty of Art and Science, Chemistry Department, 34220, İstanbul, Turkey (ORCID: 0000-0002-7412-7800), kuzzynobo@yahoo.com \\ ${ }^{2 *}$ Innova Gold Group, Merkez Mah. Ladin Sok. No:4/B001 Yenibosna, İstanbul, Turkey
}

(First received 26 April 2021 and in final form 24 September 2021)

(DOI: 10.31590 /ejosat.928133)

ATIF/REFERENCE: Chormey, D.S. (2021). Determination of Fenobucarb and Chlorbenside in Wastewater and Lake Water Samples by Gas Chromatography Mass Spectrometry. European Journal of Science and Technology, (27), 518-521.

\begin{abstract}
The advent of pesticide production on large scale has contributed immensely to the quality and quantity of agricultural products, and averting diseases that stem from pest vectors. Despite these benefits, inappropriate or excessive usage of these chemicals could have negative impacts on humans and other organisms in the environment. Thus, this study was designed to detect and quantify fenobucarb and chlorbenside in wastewater and lake water samples by a gas chromatograph system coupled to a mass selective detector. A suitable temperature program was used to elute the two analytes at distinct retention times, and satisfactory system performance values were obtained under optimum conditions. All standard solutions and spiked samples were gravimetrically prepared in order to enhance the accuracy of quantification. The analytes were not detected in the two test samples, but spike recovery experiments were performed to validate the accuracy of the method. Percent recoveries calculated using the external calibration method were below $75 \%$. Thus, matrix matching calibration method was used to mitigate matrix effects to obtain approximately $100 \%$ recovery results for five different spike concentrations.
\end{abstract}

\section{Fenobucarb ve Klorbensit Pestisitlerinin Atıksu ve Göl Suyu Örneklerinde Gaz Kromatografi-Kütle Spektrometresi ile Tayini}

Öz

Pestisit üretiminin büyük ölçekte gelişimi tarım ürünlerinin kalitesinin ve miktarının artmasına önemli ölçüde katkıda bulunmaktadır ve haşere türlerden kaynaklanan hastalıkları engellemektedir. Bu faydalara rağmen, bu kimyasalların uygunsuz ve aşırı miktarlarda kullanımı insanlar ve çevredeki diğer organizmalar üzerinde olumsuz etkilere neden olabilmektedir. Bu nedenle, bu çalışma fenobucarb ve klorbensit pestisitlerinin atıksu ve göl suyu örneklerinde kütle seçici dedektör ile birleştirilmiş bir gaz kromotografi sistemi ile kalitatif ve kantitatif olarak tespit edilmesi amacıyla tasarlanmıştır. Bu iki analiti farklı alıkonma sürelerinde ayırmak için uygun bir sıcaklık programı kullanılmış ve optimum koşullar altında tatmin edici sistem performans değerleri elde edilmiştir. Tayin sonuçlarının doğruluğunun arttırılması için tüm standart çözeltiler ve standart ilave edilmiş örnekler gravimetrik olarak hazırlanmıştır. Analitler her iki test örneğinde de tespit edilmemiştir fakat yöntemin doğruluğunu değerlendirmek amacıyla standart ilave edilmiş geri kazanım çalışmaları yapılmıştır. Dış standart yöntemi kullanılarak hesaplanan yüzde geri kazanım değerleri \%75'in altında elde edilmiştir. Bu nedenle, matriks etkilerini azaltmak amacıyla beş farklı standart ilave edilmiş derişim için matriks eşleştirmeli kalibrasyon yöntemi kullanılmış ve \%100'e yakın geri kazanım sonuçları elde edilmiştir.

Anahtar Kelimeler: Fenobucarb; Klorbensit; Pestisit; GC-MS; Atıksu; Kuyu suyu.

\footnotetext{
* Corresponding Author: kuzzynobo@yahoo.com
} 


\section{Introduction}

Pest control is a very critical practice in agriculture and public health, as it ensures crop integrity (quality and quantity) and disease prevention, respectively (Aktar, Sengupta, \& Chowdhury, 2009). Pesticides are natural and synthetic chemicals that are used to eradicate pests that pose harm to humans and other organisms (Bahlai, Xue, McCreary, Schaafsma, \& Hallett, 2010). Production of synthetic pesticides increased on a major scale in the mid 1940's upon the discovery of dichlorodiphenyltrichloroethane (DDT) as an effective insecticide against insects bearing pathogens that cause diseases such as malaria and typhus (Conis, 2010; Sadasivaiah, Tozan, \& Breman, 2007). Despite these prominent advantages accrued from pesticide usage, there are several negative impacts that have been reported for their exposure to humans, animals and the environment. Some health effects that are associated with pesticide exposure include Parkinson's disease, reproductive disorders, breast cancer, prostate cancer, and tumors of the brain, liver, lungs and endocrine glands (Brouwer et al., 2017; Sabarwal, Kumar, \& Singh, 2018; Thongprakaisang, Thiantanawat, Rangkadilok, Suriyo, \& Satayavivad, 2013). Pesticides can be classified based on their chemical class, target organism, mode of action, mode of application, amongst others (Jayaraj, Megha, \& Sreedev, 2016). Organochlorine pesticides, organophosphate pesticides, carbamate pesticides and pyrethoid pesticides are the four main groups of pesticides classified according to their chemical source (Hassaan \& El Nemr, 2020). Among these chemical classes, the organochlorines are considered to be very persistent in the environment, posing toxic risks on organisms (Pleština, 2003).

Chlorbenside is an organochlorine pesticide by its chemical class and an acaricide according to its target organism such as mites and ticks. It possesses very efficient ovicidal and larvicidal activities, and it is mostly applied to fruits and other crops prior to their blossom stage (Müller, Streibert, \& Farooq, 2009). The persistence of chlorbenside in soil is quite low and it is therefore oxidized into sulfoxide or sulfone in the presence of air. Chlorbenside is an obsolete pesticide that is prohibited from use by the European Union (Commission, 2020). The International Union of Pure and Applied Chemistry describes chlorbenside as a toxicant to the liver and kidneys, and hazardous to the digestive tract system (IUPAC, 2020a). Fenobucarb is another obsolete pesticide that belongs to the carbamate chemical class of pesticides, and it was used as an effective insecticide on farmlands. It was mostly used on cotton and rice farmlands, where it had the potential to leech down into groundwater, or run-off into other surface waters (Zhu et al., 2020). Some human health issues associated with Fenobucarb as stated by IUPAC are skin and eye irritation, inhibition of acetyl cholinesterase and a neurotoxicity (IUPAC, 2020b). The chemical structures of chlorbenside and fenobucarb are given in Figure 1.<smiles>CCC(C)c1ccccc1OC(=O)NC</smiles><smiles>Clc1ccc(CSc2ccc(Cl)cc2)cc1</smiles>

Gas chromatography is a very useful chromatographic method for the separation of volatile organic compounds, and it can be coupled to several detector systems to detect and quantify compounds (Forgács \& Cserháti, 2003a). Some common detectors that are coupled to GC systems are electron capture detector (ECD), flame ionization detector (FID), thermal conductivity detector (TCD), flame photometric detector (PID) and nitrogen phosphorus detector (NPD) (Forgács \& Cserháti, 2003a, 2003b). The mass selective detector (MSD) is a very powerful tool that when combined with gas chromatography (GC-MS) allows the determination of compounds with high accuracy and precision, and unknown compounds can be further separated and characterized based on different fragmentation patterns (Lindon, Tranter, \& Koppenaal, 2016).

The objective of this study was to use GC-MS to separate, detect and quantify chlorbenside and fenobucarb in wastewater and lake water samples, with high accuracy and precision.

\section{Material and Method}

\subsection{Instrumentation}

A $30 \mathrm{~m}$ non-polar capillary column (HP-5MS, $250 \mu \mathrm{m}$ i.d., $0.25 \mu \mathrm{m}$ film thickness) fitted to a gas chromatograph (Agilent 6890) and mass selective detector (Agilent 5973) was used for separation, detection and quantification of fenobucarb and chlorbenside. The following temperature ramp program was used to elute the analytes through the column into the detector: $30{ }^{\circ} \mathrm{C} / \mathrm{min}$ from $100{ }^{\circ} \mathrm{C}$ (initial temperature) to $200{ }^{\circ} \mathrm{C}$, $15{ }^{\circ} \mathrm{C} / \mathrm{min}$ to $240{ }^{\circ} \mathrm{C}$ and $50{ }^{\circ} \mathrm{C} / \mathrm{min}$ to $290{ }^{\circ} \mathrm{C}$. The splitless injection mode was employed for all samples and standards, and the injection volume was $1.0 \mu \mathrm{L}$. Temperature of the injection port was $250{ }^{\circ} \mathrm{C}$, and the respective temperatures set for the auxiliary line, MS Source and MS Quad were $280{ }^{\circ} \mathrm{C}, 230{ }^{\circ} \mathrm{C}$ and $150{ }^{\circ} \mathrm{C}$. The carrier gas $(99.999 \%$ helium gas) was programed to flow constantly at a rate of $2.5 \mathrm{~mL} / \mathrm{min}$. Using the standard ionization energy of $70 \mathrm{eV}$, fenobucarb and chlorbenside were qualified/quantified with the fragment ions $(\mathrm{m} / \mathrm{z}) \mathbf{1 2 7 / 1 2 5}$ and 150/121, respectively.

\subsection{Chemicals}

High purity standards ( $>98 \%$ ) of fenobucarb (CAS\# 376681-2) and chlorbenside (CAS\# 103-17-3) were purchased from Dr. Erhrenstorfer (Augsburg - Germany). Appropriate amounts were dissolved in acetonitrile to prepare stock standard solutions with approximate concentrations of $1.0 \mathrm{~g} / \mathrm{kg}$. Mixed intermediate and calibration standard solutions were prepared by making appropriate dilutions of the stock solutions.

\subsection{Samples}

Water was sampled from a Lake at a depth of about $1.0 \mathrm{~m}$ into a clean $500 \mathrm{~mL}$ polypropylene bottle. The bottle was rinsed about five times with the lake water prior to filling the bottle to the brim. The wastewater sample used in this study was sampled similar to the lake water sample from the open-to-air influent pool at a biological wastewater treatment plant in İstanbul (Turkey). Both aqueous samples were filtered successively through $11 \mu \mathrm{m}$ regular filter paper and $0.45 \mu \mathrm{m}$ syringe filter to remove particulate matter.

Figure 1. Chemical structures of fenobucarb (left) and chlorbenside (right). 


\section{Results and Discussion}

All samples and standard solutions were prepared gravimetrically to enhance the accuracy of quantification. Quadruplicate measurements were performed for samples and standards to determine the precision (repeatability) of the method.

\subsection{Qualitative and quantitative analysis}

A moderate temperature ramp program (Section 2.1) was employed for complete separation of fenobucarb and chlorbenside, making up a total run time of $7.0 \mathrm{~min}$. The extract ion chromatogram of Figure 2 shows fenobucarb and chlorbenside eluted at the retention times of 3.76 and 6.19 min, respectively. The analytes were confirmed by extracting their mass spectra information and comparing them to the database of compounds compiled by the National Institute of Science and Technology (NIST). Single standards were also sent to the GCMS system and the peaks obtained conformed to the peaks recorded for the mixed standards. Calibration standard solutions prepared in the linear dynamic range of $1.0-100 \mathrm{mg} / \mathrm{kg}$ were measured, integrated and the peak area values were used to develop calibration plots that produced coefficient of determination values greater than 0.9998. Both analytes recorded signal-to-noise (S/N) ratios greater 3 for the $1.0 \mathrm{mg} / \mathrm{kg}$ calibration standard. As the lowest calibration standard, 1.0 $\mathrm{mg} / \mathrm{kg}$ was measured seven times and the peak area values obtained were used to calculate standard deviation (StdDev) values for the analytes. The limits of detection (LOD) and quantification (LOQ), and percent relative standard deviation (\%RSD) values were calculated using the following respective expressions: $\quad 3 *$ StdDev/slope, $10 *$ StdDev/slope and StdDev/Average* 100 . Values of the parameters used to validate the GC-MS system for the analytes are summarized in Table 1.

\subsection{Lake water recovery}

Farmlands are preferably located close to lakes with the aim of using the water source to irrigate crops regularly throughout the year. The proximity of farmlands to lakes makes them susceptible to contamination from chemicals such as pesticides that are used for pest control. Also, lakes and other surface waters are exposed to anthropogenic and natural matter that alter their matrix and potentially affect the determination of analytes. Thus, water sampled from a lake was analyzed by the GC-MS system but fenobucarb and chlorbenside were not detected, with respect to their detection limits. Spike recovery experiments were then performed by spiking the lake water samples with intermediate standard solutions that were 100 times higher than the desired spike concentrations. This was done to ensure that the lake water matrix would not be significantly diluted or altered by the standard solution. The percent recoveries calculated for the sample spiked at approximately 1.0, 2.5, 5.0, 10 and $25 \mathrm{mg} / \mathrm{kg}$ were below $75 \%$, using the external calibration plot of standard solutions prepared in ethanol. To improve upon these results, matrix matching calibration standards were prepared with a different lake water sample and used to develop six-point calibration plots with $\mathrm{R}^{2}$ values $\geq 0.9998$. Satisfactory results were obtained with the matrix matching method as given in Table 2.

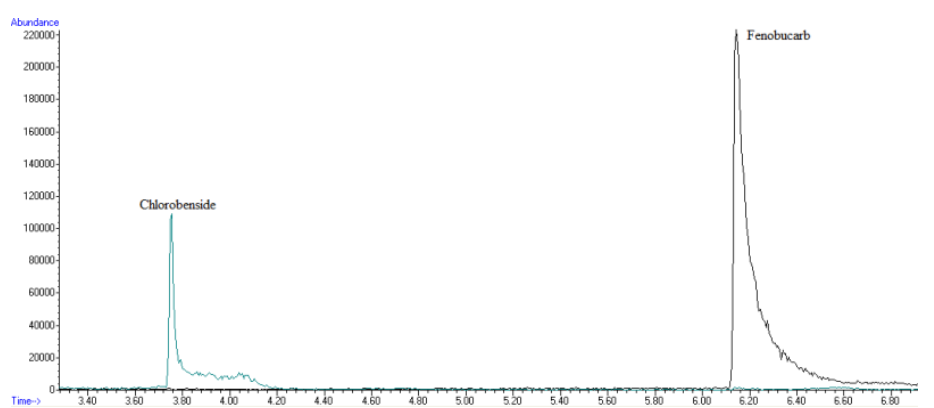

Figure 1. Extract ion chromatogram of $50 \mathrm{mg} / \mathrm{kg}$ mixed standard solution showing well-separated peaks of chlorbenside and fenobucarb.

Table 1. Analytical figures of merit of the GC-MS system for chlorbenside and fenobucarb.

\begin{tabular}{ccc}
\hline Parameter & Chlorbenside & Fenobucarb \\
\hline LOD, $\mathrm{mg} / \mathrm{kg}$ & 0.28 & 0.30 \\
\hline LOQ, $\mathrm{mg} / \mathrm{kg}$ & 0.95 & 1.0 \\
\hline $\mathrm{LDR}, \mathrm{mg} / \mathrm{kg}$ & $1.0-100$ & $1.0-50$ \\
\hline $\mathrm{R}^{2}$ & 0.9998 & 0.9999 \\
\hline Intra-day \%RSD & 8.3 & 10.0 \\
\hline Inter-day \%RSD & 9.1 & 8.9 \\
\hline
\end{tabular}

Table 2. Percent recovery results calculated for spiked lake water samples.

\begin{tabular}{ccc}
\hline \multirow{2}{*}{ Spike Concentration } & Chlorbenside & Fenobucarb \\
\cline { 2 - 3 } & \%Recovery & \%Recovery \\
\hline $1.0 \mathrm{mg} / \mathrm{kg}$ & $98.8 \pm 6.7 \%$ & $98.4 \pm 6.1 \%$ \\
\hline $2.5 \mathrm{mg} / \mathrm{kg}$ & $99.1 \pm 4.1 \%$ & $99.7 \pm 3.8 \%$ \\
\hline $5.0 \mathrm{mg} / \mathrm{kg}$ & $100.5 \pm 9.8 \%$ & $101.7 \pm 7.1 \%$ \\
\hline $10 \mathrm{mg} / \mathrm{kg}$ & $100.2 \pm 2.8 \%$ & $99.2 \pm 9.1 \%$ \\
\hline $25 \mathrm{mg} / \mathrm{kg}$ & $99.6 \pm 8.3 \%$ & $100.6 \pm 7.3 \%$ \\
\hline
\end{tabular}

\subsection{Wastewater recovery}

The matrix of wastewater samples tend to be very complex due to the presence of multiple inorganic and organic compounds, as well as particulate matter. The complexity of wastewater significantly impacts the accuracy of determining analytes of interest. Interferents may either cause positive errors (greater than true value) or negative errors (less than true value), both events that are not desired in the quantification of analytes. Similar to the lake water samples, blank determinations were performed before the spiking experiments and the analytes were not detected. The spiked wastewater samples were quantified with the external calibration method and the results obtained $(<70 \%)$ were similarly low as observed for the lake water samples. The wastewater recovery results were slightly lower than those recorded for the lake water samples due to its more complex matrix. Thus, the matrix matching calibration method 
was applied to enhance the accuracy of quantification, and the results obtained (Table 3) ranged between 96 and 103\%.

Table 3. Percent recovery results calculated for spiked wastewater samples.

\begin{tabular}{ccc}
\hline & Chlorbenside & Fenobucarb \\
\cline { 2 - 3 } Spike Concentration & \%Recovery & \% Recovery \\
\hline $1.0 \mathrm{mg} / \mathrm{kg}$ & $102.9 \pm 6.9 \%$ & $102.2 \pm 6.8 \%$ \\
\hline $2.5 \mathrm{mg} / \mathrm{kg}$ & $100.2 \pm 3.1 \%$ & $96.7 \pm 5.2 \%$ \\
\hline $5.0 \mathrm{mg} / \mathrm{kg}$ & $99.3 \pm 9.0 \%$ & $99.2 \pm 3.1 \%$ \\
\hline $10 \mathrm{mg} / \mathrm{kg}$ & $100.0 \pm 6.8 \%$ & $101.4 \pm 6.3 \%$ \\
\hline $25 \mathrm{mg} / \mathrm{kg}$ & $100.2 \pm 2.1 \%$ & $98.7 \pm 1.7 \%$
\end{tabular}

\section{Conclusions and Recommendations}

In the present study, gas chromatography mass spectrometry was used for the direct determination of fenobucarb and chlorbenside in wastewater and lake water samples. An appropriate temperature program was used for complete separation of the two analytes within a run time of $7.0 \mathrm{~min}$. Lake and wastewater samples tend to have complex matrices that could influence the accuracy of quantifying analytes. Matrix matching calibration strategy was used to overcome the drawback of the external calibration method for the two samples. Percent recovery results calculated for the samples spiked at five different concentrations were in the range of $96-103 \%$, and the relative standard deviation values calculated below $10 \%$ certified good repeatability for the method.

\section{References}

Aktar, M. W., Sengupta, D., \& Chowdhury, A. (2009). Impact of pesticides use in agriculture: their benefits and hazards. Interdisciplinary Toxicology, 2(1), 1-12. doi:10.2478/v10102-009-0001-7

Bahlai, C. A., Xue, Y., McCreary, C. M., Schaafsma, A. W., \& Hallett, R. H. (2010). Choosing organic pesticides over synthetic pesticides may not effectively mitigate environmental risk in soybeans. PloS One, 5(6), e11250-e11250. doi:10.1371/journal.pone.0011250

Brouwer, M., Huss, A., van der Mark, M., Nijssen, P. C. G., Mulleners, W. M., Sas, A. M. G., . . . Vermeulen, R. C. H. (2017). Environmental exposure to pesticides and the risk of Parkinson's disease in the Netherlands. Environment International, 107, 100-110. doi:https://doi.org/10.1016/j.envint.2017.07.001

Commission, E. (2020). EU Pesticides database: Chlorbenside. Retrieved from https://ec.europa.eu/food/plant/pesticides/eu-pesticidesdatabase/public/?event=activesubstance.detail\&languag $\mathrm{e}=\mathrm{EN} \&$ selectedID $=1104$

Conis, E. (2010). Debating the health effects of DDT: Thomas Jukes, Charles Wurster, and the fate of an environmental pollutant. Public Health Reports
(Washington, D.C. : 1974), 125(2), 337-342. doi:10.1177/003335491012500224

Forgács, E., \& Cserháti, T. (2003a). 9 - Gas chromatography. In M. Lees (Ed.), Food Authenticity and Traceability (pp. 197-217): Woodhead Publishing.

Forgács, E., \& Cserháti, T. (2003b). Chromatography | Principles. In B. Caballero (Ed.), Encyclopedia of Food Sciences and Nutrition (Second Edition) (pp. 12591267). Oxford: Academic Press.

Hassaan, M. A., \& El Nemr, A. (2020). Pesticides pollution: Classifications, human health impact, extraction and treatment techniques. The Egyptian Journal of Aquatic Research, 46(3), 207-220. doi:https://doi.org/10.1016/j.ejar.2020.08.007

IUPAC. (2020a). Chlorbenside (Ref: ENT 20696). Retrieved from https://sitem.herts.ac.uk/aeru/iupac/Reports/1225.htm

IUPAC. (2020b). Fenobucarb (Ref: Bayer 41367C). Retrieved from https://sitem.herts.ac.uk/aeru/iupac/Reports/1183.htm

Jayaraj, R., Megha, P., \& Sreedev, P. (2016). Organochlorine pesticides, their toxic effects on living organisms and their fate in the environment. Interdisciplinary Toxicology, 9(3-4), 90-100. doi:10.1515/intox-20160012

Lindon, J. C., Tranter, G. E., \& Koppenaal, D. (2016). Encyclopedia of spectroscopy and spectrometry: Academic Press.

Müller, F., Streibert, H. P., \& Farooq, S. (2009). Acaricides. Ullmann's Encyclopedia of Industrial Chemistry, 91 190. doi:10.1002/14356007.a01_017.pub2

Pleština, R. (2003). Pestıcıdes and Herbicıdes | Types of Pesticide. In B. Caballero (Ed.), Encyclopedia of Food Sciences and Nutrition (Second Edition) (pp. 44734483). Oxford: Academic Press.

Sabarwal, A., Kumar, K., \& Singh, R. P. (2018). Hazardous effects of chemical pesticides on human health-Cancer and other associated disorders. Environmental Toxicology and Pharmacology, 63, 103-114. doi:https://doi.org/10.1016/j.etap.2018.08.018

Sadasivaiah, S., Tozan, Y., \& Breman, J. G. (2007). Dichlorodiphenyltrichloroethane (DDT) for indoor residual spraying in Africa: how can it be used for malaria control? American Journal of Tropical Medicine and Hygiene, 77(6 Suppl), 249-263.

Thongprakaisang, S., Thiantanawat, A., Rangkadilok, N., Suriyo, T., \& Satayavivad, J. (2013). Glyphosate induces human breast cancer cells growth via estrogen receptors. Food and Chemical Toxicology, 59, 129-136. doi:https://doi.org/10.1016/j.fct.2013.05.057

Zhu, X.-Y., Wu, Y.-Y., Xia, B., Dai, M.-Z., Huang, Y.-F., Yang, H., . . . Li, P. (2020). Fenobucarb-induced developmental neurotoxicity and mechanisms in zebrafish. NeuroToxicology, 79, 11-19. doi:https://doi.org/10.1016/j.neuro.2020.03.013 